\title{
Valor nutricional de cultivares de azevém consorciados ou não com aveia sob dois resíduos de pastejo
}

Nutritional value of ryegrass cultivars intercropped or not with oats under two waste

\section{Renato Marchesan, Wagner Paris, Roniclei Tonion, Clederson Martinello, Marcos Luis Molinete, Fabiana Luiza Matielo Paula e Rose Rocha}

Recebido em 20/02/2015 / Aceito em 29/09/2015

\section{RESUMO}

O objetivo deste estudo foi avaliar o valor nutricional de dois cultivares de azevém (Lolium multiflorum Lam.) cv. Barjumbo e cv. comum, consorciados ou não com aveia preta (Avena strigosa Schreb) cv. IAPAR 61 submetidos a dois resíduos de forragem pós-pastejo. O trabalho foi realizado na Universidade Tecnológica Federal do Paraná, Câmpus Dois Vizinhos, no período de abril a setembro de 2012. Os tratamentos foram constituídos de um bifatorial $4 \times 2$, totalizando oito tratamentos com três repetições, sendo avaliados os azevéns comum e Barjumbo solteiros ou consorciados com aveia preta em duas alturas de resíduo pós-pastejo: Alto: $50 \%$ da altura de entrada; Baixo: $30 \%$ da altura de entrada. As variáveis avaliadas foram proteína bruta (PB), fibra em detergente neutro (FDN), fibra em detergente ácido (FDA), nutrientes digestíveis totais (NDT) e digestibilidade in vitro da matéria seca (DIVMS). O Barjumbo solteiro apresentou maior PB. Os teores de FDN e FDA foram menores para o cultivar Barjumbo solteiro ou consorciado em relação ao cultivar comum e, como consequência, a DIVMS e NDT foram superiores. Dentro do período experimental, a pastagem apresentou ligeira elevação nos teores de PB, NDT e DIVMS até por volta de 100 dias após a emergência. Já os valores de FDN e FDA demonstraram uma elevação linear desde o início até o final do período de avaliações.

PALAVRAS-CHAVE: Barjumbo, digestibilidade, fibra, proteína.

\section{ABSTRACT}

The objective of this study was to evaluate the nutritional value of ryegrass (Lolium multiflorum
Lam) cv. Barjumbo and common ryegrass (Lolium multiflorum) intercropped or not with oats (Avena strigosa Schreb) cv. IAPAR 61 under two post-grazing residue. The study was conducted at the Universidade Tecnológica Federal do Paraná, Câmpus Dois Vizinhos, in the period April-September, 2012. The experimental design was a bifactorial $4 \times 2$, totaling eight treatments with three replicates, common and Barjumbo ryegrass single or intercropped with oat in two post-grazing residue: High: $50 \%$ of the input height; Low: $30 \%$ of the input height being evaluated. The variables evaluated were crude protein $(\mathrm{CP})$, neutral detergent fiber (NDF), acid detergent fiber (ADF), total digestible nutrients (TDN) and in vitro dry matter digestibility (IVDMD). The single Barjumbo had higher CP. NDF and ADF were lower for single cultivar or intercropped Barjumbo in comparison to the common cultivar and, consequently, the IVDMD and TDN were higher. Within the trial period, the grazing slightly increased the $\mathrm{CP}$ content, TDN and IVDMD until about 100 days after emergence. The NDF and ADF values have showed a linear increase from the beginning to the end of the trial period.

KEYWORDS: Barjumbo, digestibility, fiber, protein.

\section{INTRODUÇÃO}

A utilização de pastagens de clima temperado, em regiões que apresentam condições climáticas adequadas, permite aumento na disponibilidade de forragem de alta qualidade no período em que as espécies tropicais paralisam seu crescimento, proporcionando ótimos ganhos produtivos nessa época do ano, desde que bem manejadas. As espécies forrageiras mais utilizadas nesses sistemas são a aveia preta (Avena strigosa Schreb.) e o azevém (Lolium

Universidade Tecnológica Federal do Paraná, Dois Vizinhos, PR, Brasil.

*Autor para correspondência $<$ renatomarchesan@yahoo.com.br>. 
multiflorum Lam.). Na comparação entre as duas espécies, a aveia possui um ciclo de produção de forragem mais curto e mais precoce. Sendo assim, a consorciação entre as duas espécies visa proporcionar o prolongamento de período de pastejo no inverno, associando os picos de produção de matéria seca das duas espécies, aumentando a produtividade animal nessa época do ano (ROCHA et al. 2007a).

Dois tipos de germoplasmas de azevém podem ser encontrados, o mais usual é o azevém diploide (2n) que é o azevém comum, no entanto, melhoristas desenvolveram os tretraplóides (4n) que apresentam algumas características diferentes, como sementes maiores e folhas mais largas e mais escuras, como é o caso do azevém cv. Barjumbo, oriundo do Uruguai (CARVALHO et al. 2010), o que torna interessante a comparação entre um material largamente utilizado com um melhorado.

Para a entrada dos animais na pastagem há uma recomendação que seja quando a mesma atingir $95 \%$ de interceptação luminosa pelo dossel forrageiro, havendo neste ponto a máxima taxa de acúmulo de forragem (SILVA 2011). No entanto, há uma maior flexibilidade para a altura de pós-pastejo, a qual pode variar de acordo com o objetivo do pastejo, onde se pode optar por maior desempenho animal ou maior produção por área (DIFANTE et al. 2009).

O estudo do valor nutritivo das espécies forrageiras é de grande importância no manejo nutricional, pois permite obter valores reais dos nutrientes de um alimento, sendo esses necessários para um balanceamento adequado da dieta, que afeta o desempenho produtivo dos animais (BENEVIDES et al. 2007). Segundo FEROLLA et al. (2007), a quantidade de proteína diminui com o passar do ciclo da planta, pois a parede celular cresce para proporcionar estabilidade estrutural e conferir proteção aos órgãos reprodutores e às sementes, se tornando um alimento mais fibroso. Segundo o mesmo autor, os teores de proteína bruta podem variar de acordo com a época de plantio, mas o fator principal para essa variação é o estádio fisiológico da planta.

O manejo da pastagem interfere muito na qualidade, de acordo com BARBOSA et al. (2007), a qualidade da forragem é maior quando esta é manejada mais intensivamente, devido haver um crescimento constante havendo maior presença de material vegetativo mais tenro, com perfilhos e folhas jovens, as quais possuem melhor valor nutricional. PIAZZETTA et al. (2009) avaliando a qualidade de pastagens de aveia preta e azevém sob diferentes alturas de manejo $(7,14,21$ e $28 \mathrm{~cm})$ encontraram valores de proteína bruta superiores nas alturas de 7 e $14 \mathrm{~cm}$.

Neste sentido, objetivou-se avaliar o valor nutricional do azevém (Lolium multiflorum Lam.) cv. Barjumbo e do azevém comum (Lolium multiflorum) consorciados ou não com aveia (Avena strigosa Schreb) cv. IAPAR 61 submetidos a dois resíduos pós-pastejo.

\section{MATERIAL E MÉTODOS}

O trabalho foi conduzido no período de abril a setembro de 2012, no Câmpus Dois Vizinhos da Universidade Tecnológica Federal do Paraná, localizada no terceiro planalto paranaense, com altitude de $520 \mathrm{~m}$, latitude de $25^{\circ} 44^{\prime \prime}$ Sul e longitude de $54^{\circ} 04^{\prime \prime}$ Oeste, onde o clima é do tipo subtropical úmido mesotérmico (Cfa), segundo a classificação de Köppen (ALVARES et al. 2013). O solo pertence à unidade de mapeamento Nitossolo vermelho distroférrico, textura argilosa, relevo ondulado (BHERING \& SANTOS 2008). A precipitação e a temperatura máxima e mínima durante o período do experimento estão apresentadas na Figura 1, de acordo com os dados da estação meteorológica do Instituto Nacional de Meteorologia (INMET 2012). No mês de agosto ocorreu uma severa restrição pluviométrica, o que contribuiu para o término do trabalho no mês de setembro.

Após preparo do solo, no início de abril de 2012, foi realizada a semeadura das espécies, manualmente a lanço, com posterior gradagem para cobertura das sementes. A densidade de semeadura utilizada foi de 20 e $30 \mathrm{~kg} \mathrm{ha}^{-1}$ de sementes viáveis de azevém cv. Barjumbo e Comum, respectivamente, e $50 \mathrm{~kg} \mathrm{ha}^{-1}$ de sementes viáveis de aveia cv. IAPAR 61, para os tratamentos em que foi realizada a consorciação. Foi realizada adubação nitrogenada na dose de $150 \mathrm{~kg} \mathrm{ha}^{-1}$ de N, a qual foi dividida em três aplicações, após os três primeiros pastejos em cada parcela.

Os tratamentos foram constituídos de um bifatorial $4 \times 2$ (sistema forrageiro $\mathrm{x}$ alturas de saída), distribuídos em um delineamento de blocos casualizados com três repetições. As unidades experimentais foram constituídas de piquetes de $150 \mathrm{~m}^{2}$ cada, utilizando-se de estacas de madeira, isoladores e arame do tipo liso, para implantação da cerca elétrica, sendo avaliados quatro sistemas 


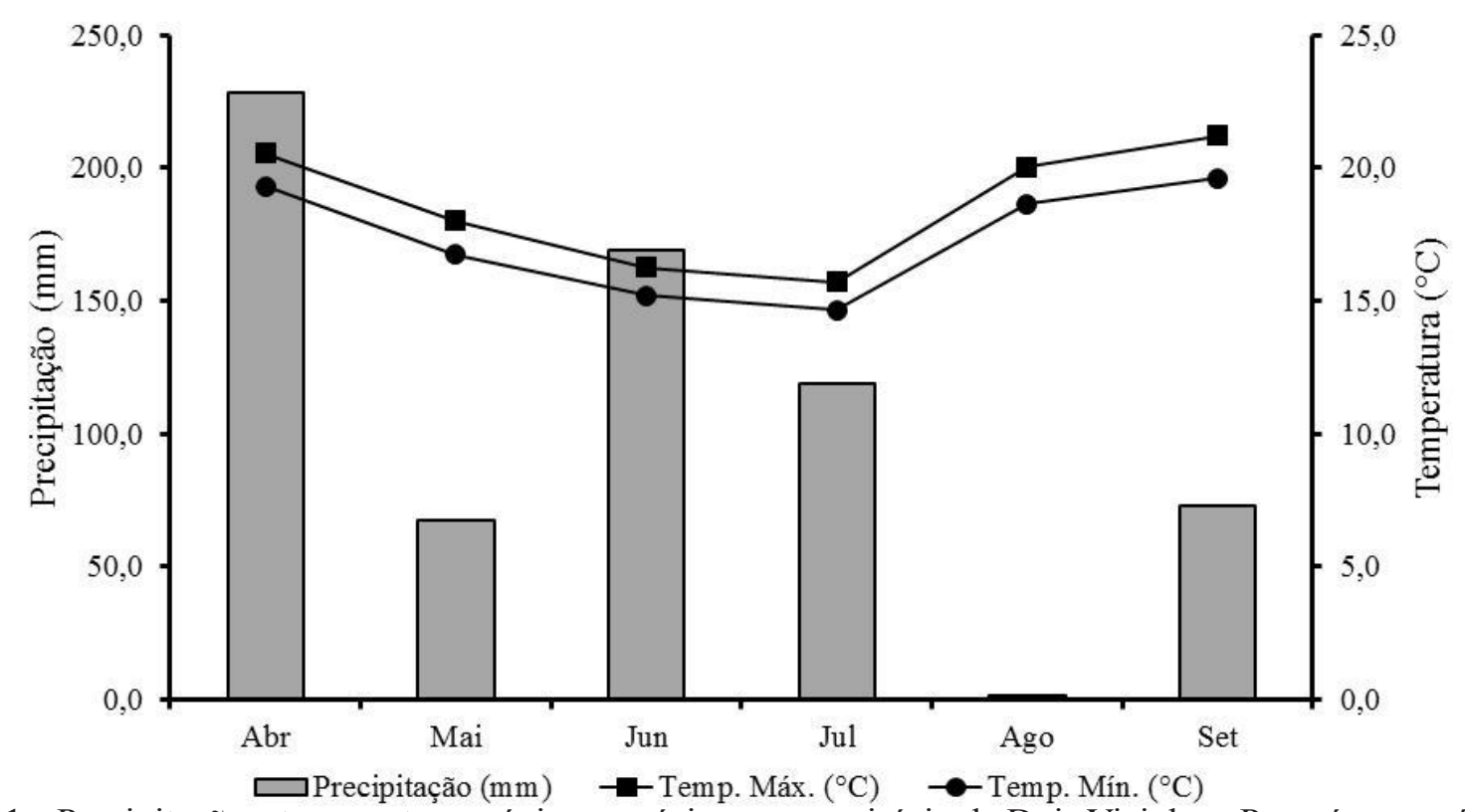

Figura 1 - Precipitação e temperatura máxima e mínima no município de Dois Vizinhos, Paraná, no período de abril a setembro de 2012. (Inmet, 2012).

Figure 1 - Rainfall and maximum and minimum temperature in the city of Dois Vizinhos, Paraná, in the period April-September 2012. (Inmet, 2012).

forrageiros (azevém comum solteiro ou consorciado e azevém Barjumbo solteiro ou consorciado) em duas alturas de resíduo pós-pastejo (Alto: $50 \%$ da altura de entrada e Baixo: $30 \%$ da altura de entrada)

Foram utilizadas vacas leiteiras da raça Jersey para o rebaixamento das pastagens até a altura desejada (alta e baixa). O tempo em que os animais permaneceram na pastagem variou com a altura de saída preconizada. Já a entrada foi realizada no momento em que a pastagem atingiu $95 \%$ de interceptação luminosa.

A determinação da interceptação luminosa foi realizada com o aparelho analisador de dossel, modelo SunScan Type SS1-COM-R4, Delta-T Services Ltda., Burwell, Cambridge, UK, realizando-se 10 leituras por piquete. A altura da pastagem foi medida, com utilização de régua graduada, nos mesmos pontos das leituras da interceptação. As alturas de entrada dos tratamentos e os intervalos entre pastejo estão apresentados na Tabela 1.

Foram coletadas quatro amostras da pastagem por piquete no dia da entrada dos animais, após foram homogeneizadas, retirando-se uma subamostra. Os cortes foram realizados rente ao solo com o auxílio de tesoura de tosquia e um quadrado de $0,25 \mathrm{~m}^{2}$. Para análise as amostras foram secas em estufa de ventilação forçada a $55^{\circ} \mathrm{C}$ por 72 horas e trituradas em moinhos de facas tipo Willey, com peneira de 1 mm. Após, foram encaminhadas ao Laboratório de Bromatologia da Universidade Tecnológica Federal do Paraná, Câmpus Dois Vizinhos, para determinação do valor nutritivo. Foram analisados os teores de proteína bruta $(\mathrm{PB})$ pelo método micro Kjeldhal (AOAC 1995), fibra detergente neutro (FDN) e fibra em detergente ácido (FDA) pelo método da Filter Bag Technique - FBT (ANKON; Macedon, New York, USA) segundo ANKOM (2014), coeficiente de digestibilidade in vitro da matéria seca (DIVMS) de acordo com a metodologia de TILLEY\& TERRY (1963) e os nutrientes digestíveis totais (NDT) foram estimados a partir da equação NDT $=$ MO $\{[26,8+$ 0,595 (MOD)]/100\}, segundo KUNKLE \& BATES (1998), onde: MO: Matéria Orgânica; MOD: Matéria orgânica digestível, a qual foi estimada através da equação MOD = -0,664 + [1,032 (DIVMS)].

Os dados obtidos foram submetidos à análise de variância e as médias comparadas através do teste t $(\mathrm{P}<0,05)$. Para avaliação no tempo (dias após a emergência) foi realizado análise de regressão a $5 \%$ de probabilidade de erro através do software SAS INSTITUTE (2001). 
Tabela 1 - Altura de entrada ao pastejo e intervalo entre pastejo dos sistemas: azevém cultivar comum e Barjumbo consorciado ou não com aveia submetidos a dois resíduos pós-pastejo, padronizado aos 95\% de interceptação luminosa.

Table 1 - Input height to grazing and range between grazing systems: ryegrass cultivar common and Barjumbo intercropped or not with oats under two post-grazing residues, standardized to 95\% light interception.

\begin{tabular}{lcccc}
\hline \multirow{2}{*}{ Altura } & \multicolumn{4}{c}{ Altura de Entrada $(\mathrm{cm})$} \\
\cline { 2 - 5 } & \multicolumn{3}{c}{ AZB $^{(1)}$} & \multicolumn{2}{c}{ AZC $^{(2)}$} \\
\hline Alto & Solteiro & Consorciado & Solteiro & Consorciado \\
Baixo & 27,18 & 33,53 & 28,60 & 33,58 \\
\hline \multirow{3}{*}{ Altura } & 26,53 & 34,48 & 28,91 & 31,38 \\
\cline { 2 - 5 } & \multicolumn{4}{c}{ Intervalo entre pastejo (dias) } \\
\cline { 2 - 5 } & Solteiro & Consorciado & Solteiro & AZC \\
\hline Alto & 30,00 & 35,00 & 22,03 & 28,90 \\
Baixo & 29,30 & 34,00 & 24,27 & 26,93 \\
\hline
\end{tabular}

${ }^{(1)}$ AZB: Azevém cultivar Barjumbo; ${ }^{(2)}$ AZC: Azevém cultivar comum; Alto: Saída com $50 \%$ da altura de entrada; Baixo: Saída com $30 \%$ da altura de entrada.

\section{RESULTADOS E DISCUSSÃO}

Não foi observada interação entre os fatores sistemas forrageiros $\mathrm{x}$ altura para nenhuma das variáveis avaliadas (Tabela 2). Porém, verificou-se efeito dos tratamentos em todas as variáveis, sem diferença entre os resíduos pós-pastejo. Isto evidencia que o valor nutritivo da pastagem é afetado pelo sistema utilizado, quando a interceptação luminosa é utilizada como parâmetro de manejo.

$\mathrm{O}$ cultivar Barjumbo solteiro apresentou maiores teores de PB que os demais tratamentos (Tabela 2), possivelmente por esse material possuir maior proporção de folhas. A inferioridade nos teores de PB, constatadas nos azevéns consorciados, em relação a sua cultivar em monocultivo, se explica pela menor proporção de folhas presentes na aveia.

Verificou-se efeito quadrático, em todos os tratamentos, para as concentrações de $\mathrm{PB}$ em função dos dias após a emergência (Figura 2). O azevém Barjumbo solteiro ou consorciado e o azevém comum solteiro ou em consórcio apresentaram picos de $\mathrm{PB}$ de $267,3,237,1,235,3$ e $260,1 \mathrm{~g} \mathrm{~kg}^{-1}$, respectivamente, com redução, após atingir o pico de 17, 29, 43 e 52\%, respectivamente. Dessa forma, nota-se que a redução dos teores de PB foi mais acentuada nos tratamentos com azevém comum, principalmente pela reduzida proporção de folhas dessa espécie. No entanto, esta queda no final do ciclo, pode ser atribuída, em parte, a baixa precipitação pluviométrica, principalmente no mês de agosto (Figura 1), o que comprometeu a produção e a qualidade das pastagens.

Segundo ROCHA et al. (2007a), ocorre modificação da estrutura da planta durante seu ciclo, devido a alteração nas proporções de lâminas foliares e colmo, o que altera os nutrientes disponíveis ao animal. PELLEGRINI et al. (2010) encontraram média de 213,0 $\mathrm{g} \mathrm{kg}^{-1}$ de proteína entre o período de agosto a novembro, avaliando produção e qualidade de azevém anual. MEDEIROS et al. (2010) avaliando desempenho e características de carcaça de novilhos terminados em pastagem de aveia preta e azevém encontraram teores de $\mathrm{PB}$ de 25,77, 25,40, 17,05, 14,59 e 8,82 para os meses de julho, agosto, setembro, outubro e novembro, respectivamente, demonstrando uma queda acentuada nos teores de PB com o avançar do estágio fenológico das plantas.

Esse efeito quadrático da PB (Figura 2) ocorreu, possivelmente, pelo fato das primeiras coletas dos materiais terem sido realizadas com no mínimo 60 dias pós emergência, e depois de cada coleta foram realizadas aplicações de nitrogênio, o que contribuiu para o aumento dos níveis de PB.

$\mathrm{O}$ azevém comum, tanto solteiro quanto consorciado, apresentou valores de FDN e FDA superiores aos tratamentos com azevém Barjumbo (Tabela 2). Esta diferença se dá pela maior proporção de colmos encontradas no cultivar comum, sendo os colmos o constituinte estrutural das plantas que apresentam maior parede celular e consequentemente maiores proporções de carboidratos fibrosos. 
Tabela 2 - Teores médios de proteína bruta, fibra em detergente neutro, fibra em detergente ácido, nutrientes digestíveis totais e digestibilidade in vitro da matéria seca dos sistemas: azevém cultivar comum e Barjumbo consorciado ou não com aveia submetidos a dois resíduos pós-pastejo.

Table 2 - Average crude protein levels available, neutral detergent fiber, acid detergent fiber, total digestible nutrients and in vitro dry matter digestibility of systems: ryegrass cultivar common and Barjumbo intercropped or not with oats under two post-grazing residues.

\begin{tabular}{|c|c|c|c|c|c|}
\hline \multirow{3}{*}{ Altura } & \multicolumn{4}{|c|}{ Proteína Bruta $\left(\mathrm{g} \mathrm{kg}^{-1}\right)$} & \multirow[b]{3}{*}{ EPM } \\
\hline & \multicolumn{2}{|c|}{$\mathrm{AZB}^{(1)}$} & \multicolumn{2}{|c|}{$\mathrm{AZC}^{(2)}$} & \\
\hline & Solteiro & Consorciado & Solteiro & Consorciado & \\
\hline Alto & 239,4 & 235 & 203,6 & 212,5 & 1,14 \\
\hline Baixo & 241,3 & 208,5 & 198,7 & 213,3 & \\
\hline Média & $240,4 \mathrm{a}$ & $221,8 \mathrm{~b}$ & $201,2 \mathrm{c}$ & $212,9 \mathrm{bc}$ & \\
\hline \multirow{3}{*}{ Altura } & \multicolumn{4}{|c|}{ Fibra em Detergente Neutro $\left(\mathrm{g} \mathrm{k}^{-1}\right)$} & \\
\hline & \multicolumn{2}{|c|}{ AZB } & \multicolumn{2}{|c|}{ AZC } & \\
\hline & Solteiro & Consorciado & Solteiro & Consorciado & EPM \\
\hline Alto & 491,5 & 501,3 & 540,6 & 513,4 & 1,85 \\
\hline Baixo & 481,1 & 494,2 & 531,1 & 533,3 & \\
\hline Média & $486,3 \mathrm{~b}$ & $497,8 \mathrm{~b}$ & $535,9 \mathrm{a}$ & $523,4 \mathrm{a}$ & \\
\hline \multirow{3}{*}{ Altura } & \multicolumn{4}{|c|}{ Fibra em Detergente Ácido $\left(\mathrm{g} \mathrm{kg}^{-1}\right)$} & \\
\hline & \multicolumn{2}{|c|}{ AZB } & \multicolumn{2}{|c|}{$\mathrm{AZC}$} & \\
\hline & Solteiro & Consorciado & Solteiro & Consorciado & EPM \\
\hline$\overline{\text { Alto }}$ & 247,7 & 253 & 269 & 256 & 1,03 \\
\hline Baixo & 245,7 & 240,5 & 268,7 & 270 & \\
\hline Média & $246,7 \mathrm{~b}$ & $246,7 \mathrm{~b}$ & $268,8 \mathrm{a}$ & $262,7 \mathrm{a}$ & \\
\hline \multirow{3}{*}{ Altura } & \multicolumn{4}{|c|}{ Nutrientes Digestíveis Totais $\left(\mathrm{g} \mathrm{kg}^{-1}\right)$} & \\
\hline & \multicolumn{2}{|c|}{ AZB } & \multicolumn{2}{|c|}{ AZC } & \\
\hline & Solteiro & Consorciado & Solteiro & Consorciado & EPM \\
\hline Alto & 598 & 606,1 & 563 & 591,4 & 2,85 \\
\hline Baixo & 590,9 & 627,9 & 564,5 & 552,1 & \\
\hline Média & $594,4 \mathrm{ab}$ & $617,0 \mathrm{a}$ & $563,7 \mathrm{~b}$ & $571,7 \mathrm{~b}$ & \\
\hline \multirow{3}{*}{ Altura } & \multicolumn{4}{|c|}{ Digestibilidade In Vitro da Matéria Seca $\left(\mathrm{g} \mathrm{kg}^{-1}\right)$} & \\
\hline & \multicolumn{2}{|c|}{$\mathrm{AZB}$} & \multicolumn{2}{|c|}{ AZC } & \\
\hline & Solteiro & Consorciado & Solteiro & Consorciado & EPM \\
\hline Alto & 677,9 & 679,8 & 591,3 & 658,3 & 4,58 \\
\hline Baixo & 666,7 & 680,7 & 607,6 & 610,3 & \\
\hline Média & $672,3 \mathrm{a}$ & $680,2 \mathrm{a}$ & $599,5 \mathrm{~b}$ & $634,5 \mathrm{ab}$ & \\
\hline
\end{tabular}




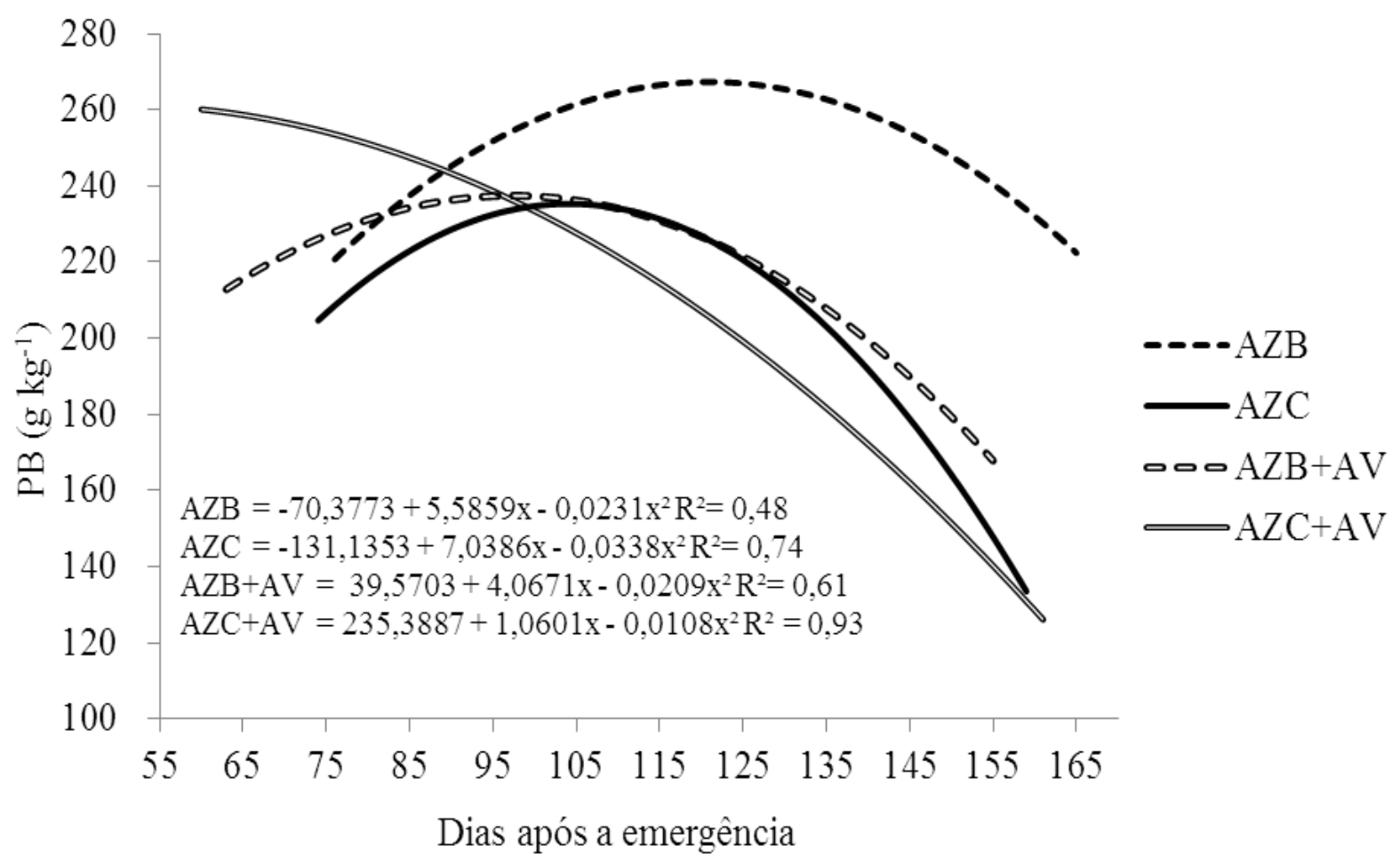

Figura 2 - Teores de proteína bruta dos sistemas: azevém cultivar comum e Barjumbo consorciado ou não com aveia durante o período de inverno.

Figure 2 - Crude protein level of sistems: ryegrass cultivar common and Barjumbo intercropped or not with oats during the winter period.

TONETTO et al. (2011) avaliando cinco genótipos de azevém, explica essa diferença, pois verificaram que os teores de $\mathrm{FDN}$ das folha não passaram de $450 \mathrm{~g} \mathrm{~kg}^{-1}$, enquanto que para o colmo os valores chegaram próximos a $700 \mathrm{~g} \mathrm{~kg}^{-1}$. Valores inferiores foram encontrados por ROCHA et al. (2007a) que avaliaram FDN da mistura de aveia e azevém comum e encontraram média $437,0 \mathrm{~g} \mathrm{~kg}^{-1}$. GERDES et al. (2005) verificaram teores maiores de FDA, 284,0 e 336,0 $\mathrm{g} \mathrm{kg}^{-1}$ para aveia e azevém comum, respectivamente.

Com o avançar do estágio fenológico (dias após a emergência), todos os tratamentos apresentaram um efeito linear positivo, com aumento dos teores de FDN com o avançar dos dias após a semeadura (Figura 3). Verifica-se também que os aumentos nos teores de FDN do azevém comum foram mais acentuados que os do cultivar Barjumbo, atingindo, ao final do ciclo, teores acima de $600 \mathrm{~g} \mathrm{~kg}^{-1}$, enquanto que os tratamentos com o cultivar Barjumbo não passaram de $550 \mathrm{~g} \mathrm{~kg}^{-1}$. De acordo com VAN SOEST (1983) os teores de fibra aumentam de acordo com o avanço do ciclo da pastagem e está associado ao aumento da massa de colmos, que possui valores maiores de FDN e FDA. Segundo MERTENS et al. (1996), elevados níveis de FDN no alimento reduzem o consumo de matéria seca, podendo ser menor do que $2,0 \%$ do peso vivo com FDN de $60 \%$.

$\mathrm{Na}$ avaliação dos teores de FDA em função dos dias após a semeadura (Figura 4), notaram-se variação linear positiva, similar aos teores de FDN. O azevém Barjumbo alcançou teor de FDA máximo de $275,0 \mathrm{~g} \mathrm{~kg}^{-1}$ quando solteiro e o consórcio do mesmo com aveia chegou a $269,0 \mathrm{~g} \mathrm{~kg}^{-1}$, enquanto que o azevém comum chegou a $291,0 \mathrm{~g} \mathrm{~kg}^{-1}$ quando solteiro e o consórcio deste azevém com aveia alcançou $299,0 \mathrm{~g} \mathrm{~kg}^{-1}$ ao final do ciclo. Segundo ROCHA et al. (2007b) a redução da proporção de folhas, o aumento de colmo e a lignificação das paredes celulares são responsáveis pela redução da qualidade bromatológica das pastagens. No entanto, esses resultados foram bastante afetados pelo reduzido índice pluviométrico no final do período de avaliação, que contribuiu para reduzir o ciclo das pastagens e sua qualidade.

$\mathrm{O}$ azevém Barjumbo consorciado foi superior ao azevém comum solteiro ou consorciado, no entanto mostrou-se estatisticamente igual ao azevém Barjumbo solteiro em relação ao NDT (Tabela 2). 


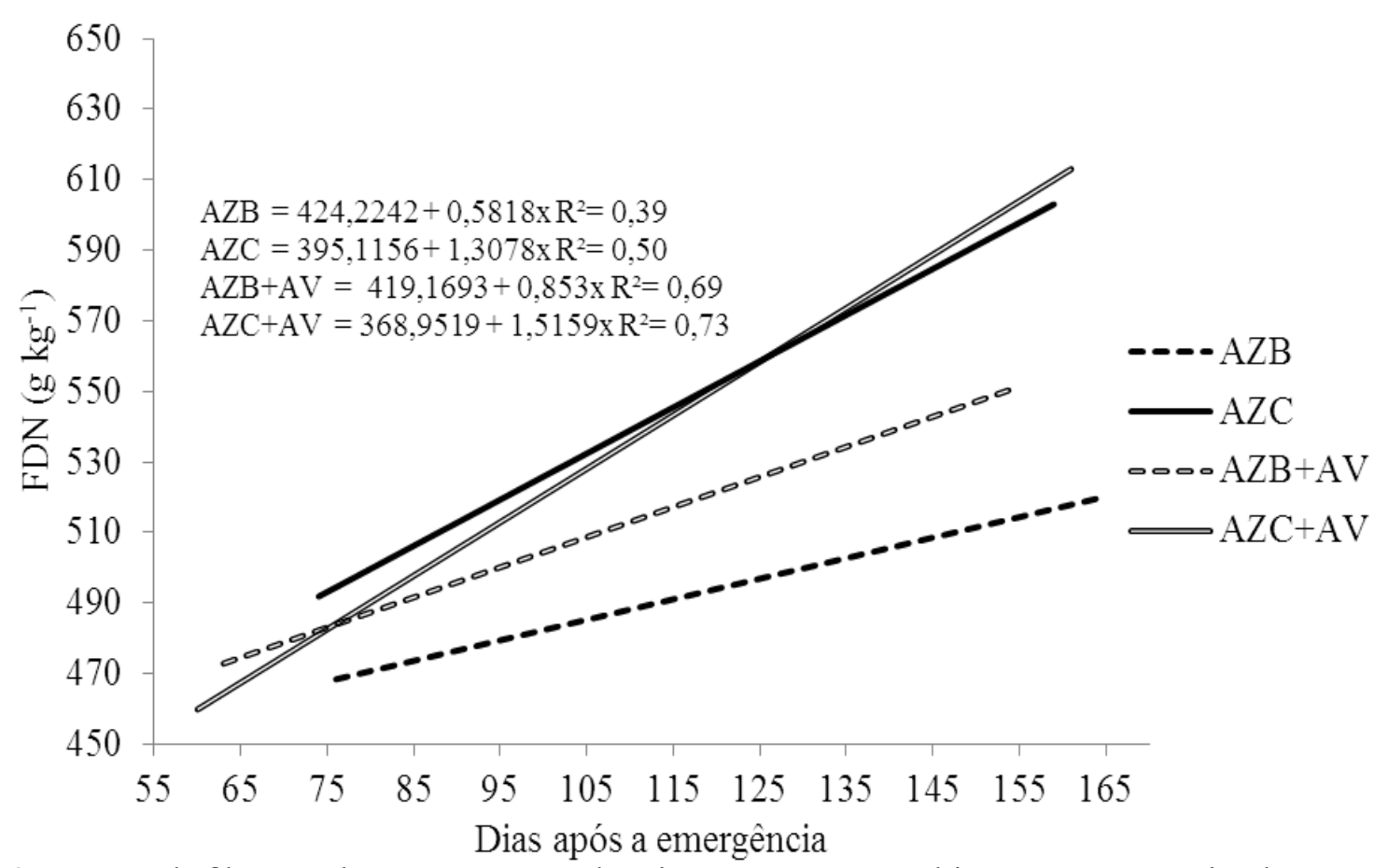

Figura 3 - Teores de fibra em detergente neutro dos sistemas: azevém cultivar comum e Barjumbo consorciado ou não com aveia durante o período de inverno.

Figure 3 - Neutral detergent fiber level of sistems: ryegrass cultivar common and Barjumbo intercropped or not with oats during the winter period.

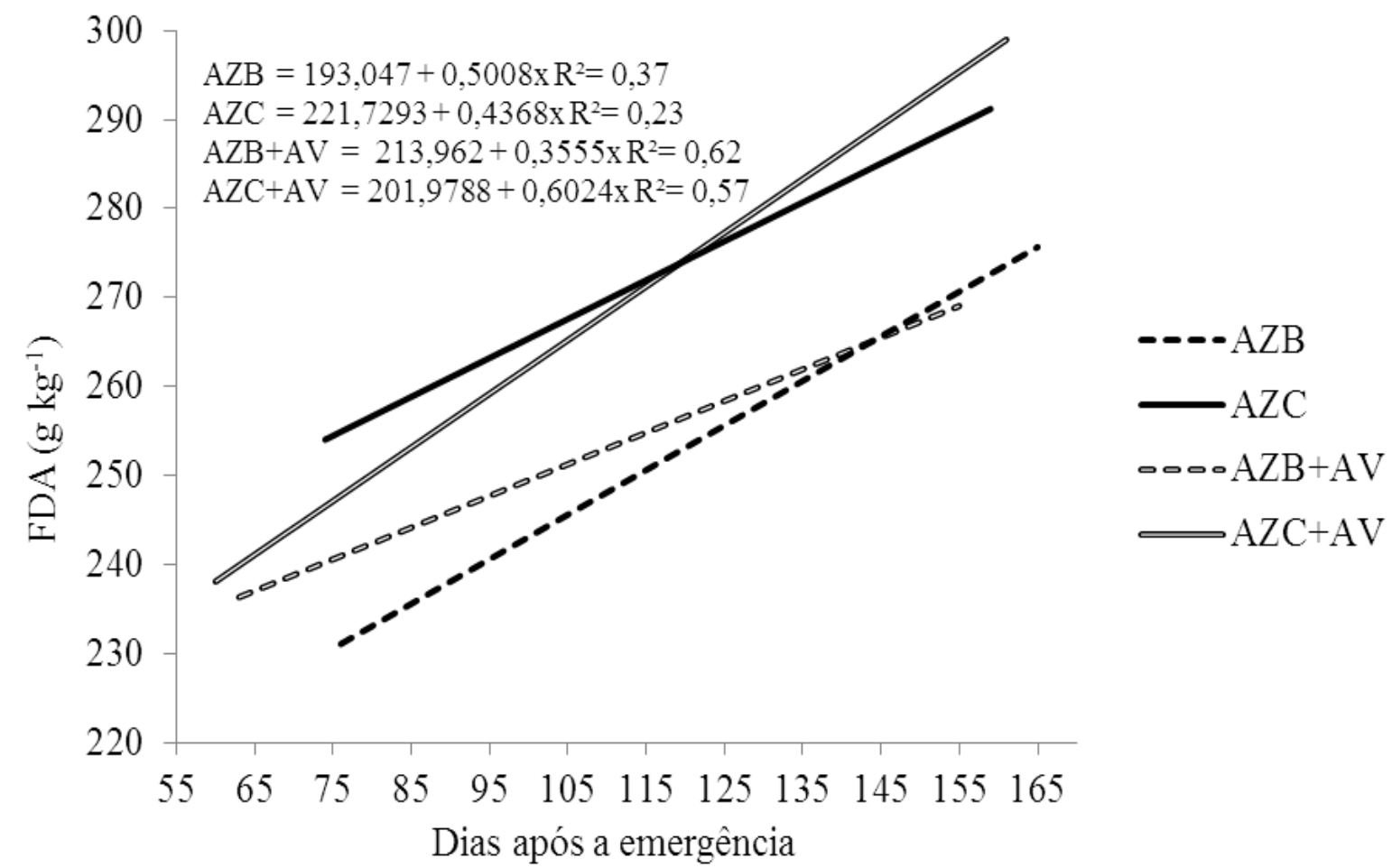

Figura 4 - Teores de fibra em detergente ácido dos sistemas: azevém cultivar comum e Barjumbo consorciado ou não com aveia durante o período de inverno.

Figure 4 - Acid detergent fiber level of sistems: ryegrass cultivar common and Barjumbo intercropped or not with oats during the winter period. 
Isso demonstra, novamente, a qualidade superior do azevém Barjumbo sobre o cultivar comum, mesmo quando consorciados com aveia. OLIVO et al. (2009) observaram teores de NDT de $611,6 \mathrm{~g} \mathrm{~kg}^{-1}$, para o azevém comum durante o período hibernal. O NDT da mistura de azevém comum com aveia encontrado por PROHMANN et al. (2004) foi de $633,0 \mathrm{~g} \mathrm{~kg}^{-1}$, na avaliação da suplementação de bovinos em pastagens.

Com o avanço do estágio fenológico todos os tratamentos apresentaram efeito quadrático para os teores de NDT (Figura 5), com ligeiro aumento e posterior redução até o final do ciclo. No entanto, observou-se que o azevém comum, solteiro ou consorciado, apresentou redução mais acentuada nos níveis de NDT, os quais reduziram 24 e 28\%, respectivamente, após alcançarem o pico. Nos tratamentos com o cultivar Barjumbo, além de um pico maior nos níveis de NDT, foi observado redução de $20 \%$ quando solteiro e $14 \%$ no consórcio, sendo essa queda maior no consórcio possivelmente pelo fato da aveia ter menores teores de NDT. O efeito quadrático do NDT, assim como ocorreu para $\mathrm{PB}$, aconteceu pelas primeiras coletas terem sido realizadas com no mínimo 60 dias após a semeadura, que foi o tempo necessário para que a pastagem absorva $95 \%$ da interceptação luminosa, sendo que as demais coletas foram realizadas com no máximo 30 dias de intervalo, onde após as três primeiras coletas foi feito a aplicação de nitrogênio em forma de uréia, ocasionando assim um aumento nos teores de NDT.

A DIVMS diferiu entre os tratamentos (Tabela 2 ), verificando-se que o azevém comum $(599,5 \mathrm{~g}$ $\left.\mathrm{kg}^{-1}\right)$ foi inferior ao cultivar Barjumbo solteiro $(672,3$ $\mathrm{g} \mathrm{kg}^{-1}$ ) ou consorciado $\left(680,2 \mathrm{~g} \mathrm{~kg}^{-1}\right)$, porém não diferiu do azevém comum em consórcio $(634,5 \mathrm{~g} \mathrm{~kg}-$ ${ }^{1}$ ), o qual foi estatisticamente igual aos tratamentos com azevém Barjumbo. Portanto, o azevém Barjumbo mostrou-se superior ao azevém comum pela sua maior qualidade e maior proporção de folhas, além disso, percebeu-se que a aveia IAPAR 61 contribuiu para o aumento da digestibilidade quando consorciada com algum cultivar de azevém. GERDES et al. (2005) observaram valores de $764,0 \mathrm{~g} \mathrm{~kg}^{-1}$ de DIVMS para aveia preta e $719,0 \mathrm{~g} \mathrm{~kg}^{-1}$ para azevém anual.

$\mathrm{Na}$ avaliação da digestibilidade entre os dias após a emergência (Figura 6), evidenciou-se comportamento semelhante ao NDT, onde todos os tratamentos apresentaram efeito quadrático, com uma pequena elevação no início e posterior diminuição

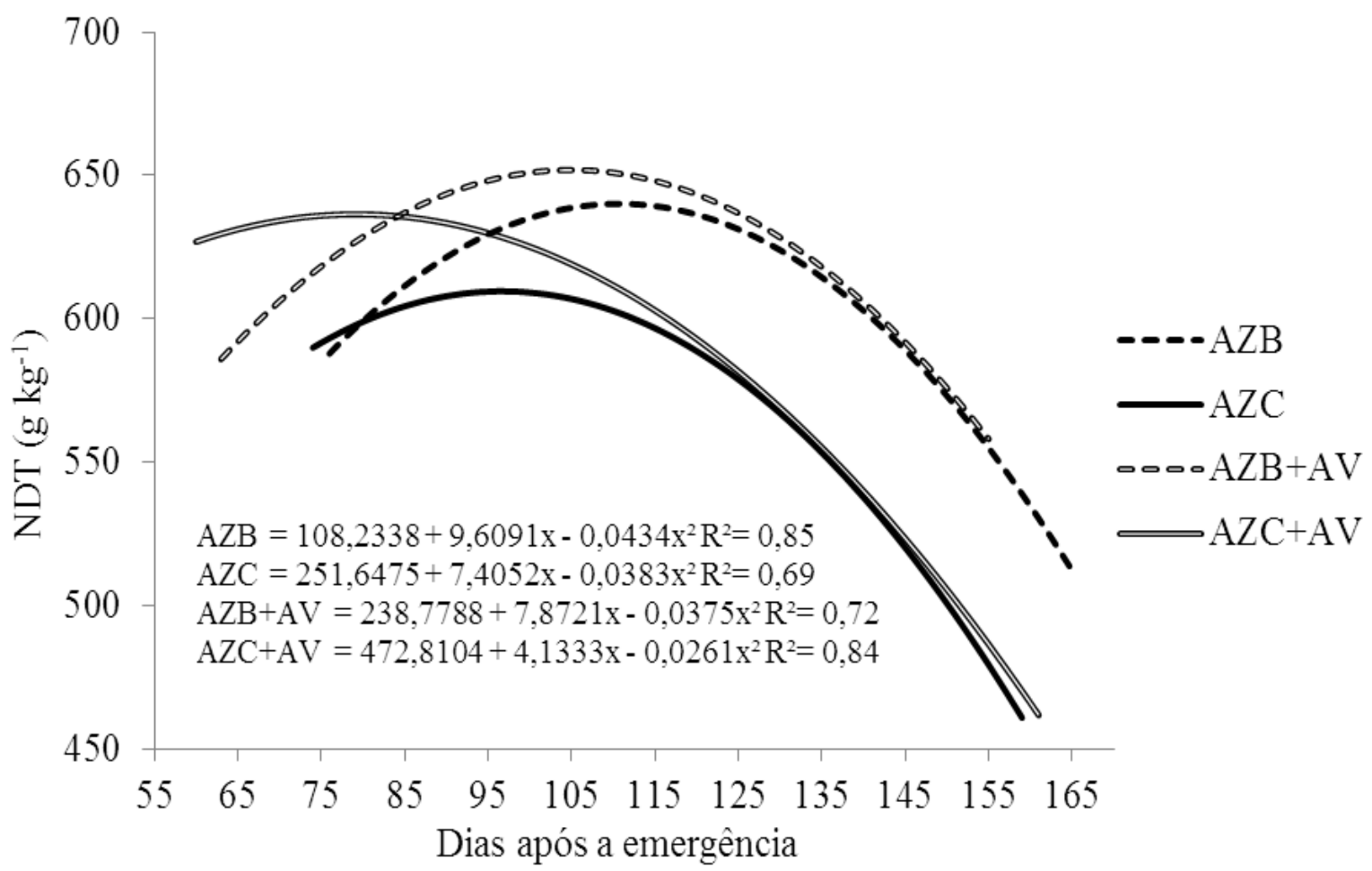

Figura 5 - Teores de nutriente digestível total dos sistemas: azevém cultivar comum e Barjumbo consorciado ou não com aveia durante o período de inverno.

Figure 5 - Total digestible nutrients level of sistems: ryegrass cultivar common and Barjumbo intercropped or not with oats during the winter period. 


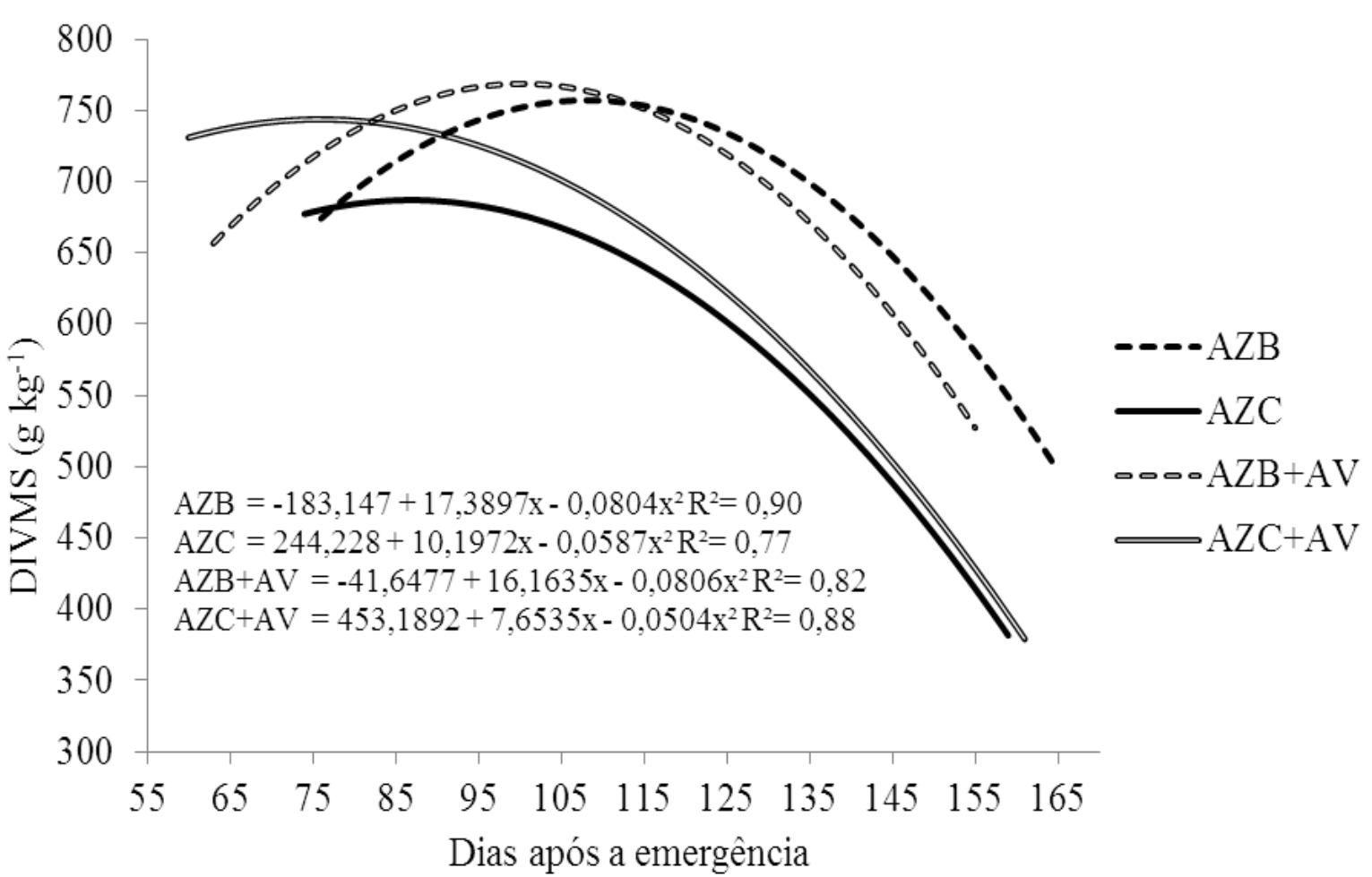

Figura 6 - Coeficiente de digestibilidade in vitro da matéria seca dos sistemas: azevém cultivar comum e Barjumbo consorciado ou não com aveia durante o período de inverno.

Figure 6 - In vitro dry matter digestibility of sistems: ryegrass cultivar common and Barjumbo intercropped or not with oats during the winter period.

até o final do ciclo. No entanto, percebeu-se que a queda na DIVMS foi mais acentuada nos tratamentos com azevém comum. Os tratamentos com azevém Barjumbo tiveram pico de DIVMS maior, além de maiores níveis no final do ciclo, com redução de 34 e $31 \%$ para o cultivo solteiro ou consorciado, respectivamente, até o final do ciclo. Enquanto que o azevém comum teve uma redução de $45 \%$, quando em monocultivo, e de $48 \%$ em consórcio com a aveia.

VELÁSQUEZ et al. (2010) verificaram maior coeficiente de digestibilidade em forragens que apresentam menores concentrações de FDN e FDA e maiores concentrações de proteína bruta e carboidratos não-fibrosos, evidenciando a relação existente entre esses nutrientes assim como no presente trabalho.

GERDES et al. (2005) verificaram diminuição nos níveis de DIVMS tanto para aveia quanto para azevém durante o período do inverno, os quais tiveram um decréscimo de 775,0 para 750,0 $\mathrm{g} \mathrm{kg}^{-1}(-3 \%)$ e de 767,0 para $614,0 \mathrm{~g} \mathrm{~kg}^{-1}(-20 \%)$, respectivamente. Dessa forma, evidenciou-se a menor qualidade das forrageiras com o avançar do estádio fenológico, pois a parede celular cresce para proporcionar estabilidade estrutural e conferir proteção aos órgãos reprodutores e às sementes (FEROLLA et al. 2007).

\section{CONCLUSÕES}

O valor nutricional da pastagem com azevém Barjumbo é superior ao do azevém comum, inclusive na avaliação dos consórcios de ambos os cultivares com aveia preta.

O azevém Barjumbo em monocultivo possui maiores teores de proteína bruta que quando no consórcio com aveia e que o azevém comum solteiro ou consorciado. A cultivar Barjumbo, em monocultivo ou consorciado com aveia IAPAR 61, apresenta os menores níveis de fibra em detergente neutro e fibra em detergente ácido.

Os nutrientes digestíveis totais e a digestibilidade in vitro matéria seca são maiores no azevém Barjumbo solteiro ou em consórcio com a aveia preta IAPAR 61.

A altura de saída do pastejo, de 30 ou $50 \%$ da altura de entrada, não altera o valor nutricional das culturas de azevéns, consorciados ou não com a aveia.

O valor nutritivo é afetado pelo estágio fenológico da planta, com redução nos teores de 
proteína bruta, digestibilidade in vitro da matéria seca e nutrientes digestíveis totais e aumento nos níveis de fibra em detergente neutro e fibra em detergente ácido, com o decorrer dos dias após a emergência.

\section{AGRADECIMENTOS}

À Coordenação de Aperfeiçoamento de Pessoal de Nível Superior (CAPES), pela concessão de bolsa de nível de mestrado ao autor.

\section{REFERÊNCIAS}

ALVARES CA et al. 2013. Köppen's climate classification map for Brazil. Meteorol. Z. 22: 711-728.

ANKOM. 2014. Filter Bag Technique. Diponível em: https: //ankom.com/neutral-detergent-fiber.aspx. Acesso em: 11 nov. 2014.

AOAC - ASSOCIATION OF OFFICIAL ANALYTICAL CHEMISTRY. 1995. Official methods of analysis. 16.ed. Arlington: AOAC International, 1025p.

BARBOSA CMP et al. 2007. Terminação de cordeiros em pastagens de azevém anual manejadas em diferentes intensidades e métodos de pastejo. R. Bras. Zootec. 36: 1953-1960.

BENEVIDES YI et al. 2007. Composição e degradabilidade da dieta de ovinos em capim tanzânia com três períodos de descanso. Arch. Zootec. 56: 215-226.

BHERING SB \& SANTOS HG. 2008. Mapa de solos do Estado do Paraná: legenda atualizada. Rio de Janeiro: EMBRAPA/IAPAR, 74p.

CARVALHO PCF et al. 2010. Característica produtiva e estrutural de pastos mistos de aveia e azevém manejados em quatro alturas sob lotação contínua. R. Bras. Zootec. 39: 1857-1865.

DIFANTE GS. 2009. Ingestive behaviour, herbage intake and grazing efficiency of beef cattle steers on Tanzania guineagrass subjected to rotational stocking managements. R. Bras. Zootec. 38: 1001-1008.

FEROLLA FS et al. 2007. Composição bromatológica e fracionamento de carboidratos e proteínas de aveia-preta e triticale sob corte e pastejo. R. Bras. Zootec. 37: 197-204. GERDES L et al. 2005. Composição química e digestibilidade da massa de forragem em pastagem irrigada de capim-aruana exclusivo ou sobre-semeado com mistura de aveia preta e azevém. R. Bras. Zootec. 34: 1098-1108.

INMET - INSTITUTO NACIONAL DE METEOROLOGIA. Consulta dados da estação automática: Dois Vizinhos (PR). Disponível em: http://www.inmet.gov. br/sonabra/pg_dsp DadosCodigo.php?QTg0Mw. Acesso em: 24 out. 2012.

KUNKLE WE \& BATES DB. 1998. Evaluating feed purchasing options: energy, protein, and mineral supplements. In: Florida Beef Cattle Short Course, Gainesville. Proceedings... Gainesville: University of
Florida, p. 119-126.

MEDEIROS FS. 2010. Desempenho e características de carcaça de novilhos terminados em pastagem de aveia preta e azevém anual com diferentes níveis de suplementação energética. Ciênc. Rural. 40: 141-148.

MERTENS D. 1996. Using fiber and carbohydrate analyses to formulate dairy rations. In: Informational Conference With Dairy And Forage Industries, Virginia. Proceedings... Virgínia: US Dairy Forage Research Center, p.81-92.

OLIVO CJ et al. 2009. Valor nutricional de forragem de pastagens manejadas durante o período hibernal. Ciênc. Rural. 39: 825-831.

PELLEGRINI LG et al. 2010. Produção e qualidade de azevém-anual submetido a adubação nitrogenada sob pastejo por cordeiros. R. Bras. Zootec. 39: 1894-1904.

PIAZZETTA RG et al. 2009. Características qualitativas da pastagem de aveia preta e azevém manejada sob diferentes alturas, obtida por simulação de pastejo. Arch. Vet. Sci. 14: 43-48.

PROHMANN PEF et al. 2004. Suplementação de Bovinos em Pastagens de Coastcross (Cynodon dactylon (L.) Pers) no Inverno. R. Bras. Zootec. 33: 801-810.

ROCHA MG et al. 2007a. Produção e qualidade de forragem da mistura de aveia e azevém sob dois métodos de estabelecimento. R. Bras. Zootec. 36: 7-15.

ROCHA MG et al. 2007b. Avaliação de espécies forrageiras de inverno na Depressão Central do Rio Grande do Sul. R. Bras. Zootec. 36: 1990-1999.

SAS INSTITUTE. SAS/STAT user's guide: statistics. Realse 8.1 Edition. Cary, 1292. p. 2001.

SILVA SC. 2011. Intensificação da produção animal em pasto por meio do manejo do pastejo In: Simpósio de Produção Animal a Pasto. Maringá: Ed. Sthampa.

TILLEY JMA \& TERRY RA. 1963. A two stage technique for the "in vitro" digestion of forage crop. J. Brit. Grass. Soc. 18: 104-111.

TONETTOCJ.2011. Produção e composição bromatológica de genótipos diplóides e tetraplóides de azevém. Zootec. Trop. 29: 169-178.

VAN SOEST PJ. 1983. Nutritional ecology of the ruminant. Corvalis: Cornell University, p.88.

VELÁSQUEZ PAT et al. 2010. Composição química, fracionamento de carboidratos e proteínas e digestibilidade in vitro de forrageiras tropicais em diferentes idades de corte. R. Bras. Zootec. 39: 1206-1213. 